\title{
PENENTUAN FORMULA UNTUK MENETAPKAN ESTIMASI KOLESTEROL-LDL
}

\author{
Gilang Nugraha ${ }^{1}$, Soebagijo Poegoeh Edijanto ${ }^{2}$ \\ ${ }^{1}$ Prodi Kedokteran, Fakultas Kedokteran, Universitas Nahdlatul Ulama Surabaya \\ ${ }^{2}$ Prodi D-IV Analis Kesehatan, Fakultas Kesehatan, Universitas Nahdlatul Ulama Surabaya \\ e-mail: : gilang@ unusa.ac.id ${ }^{1}$
}

\begin{abstract}
Measurement LDL-Cholesterol ( $L D L-C)$ can be performed by estimating $L D L-C$ (cLDL-C) in the blood. In addition to the first proposed Friedewald formula, several new formulas that promise better examination in determining LDL-C levels, proposed by Anandaraja, Puavilai, Chen, Vujovic, de Cordova and Dansethakul. The subjects of the study were patients who performed routine lipid profile examination in Institution of Clinical Pathology of Gedung Pusat Diagnostik Terpadu RSUD Dr. Soetomo Surabaya who performs 10 to 12 hours of fasting with TG less than $400 \mathrm{mg} / \mathrm{dL}$. The sample consisted of 41 men and 48 women with an average age of 52 years. The statistical test on each cLDLC gave the Friedewald $-1.32 \%$ bias value; Anandaraja -3,92\%; Puavilai 4.26\%, Chen -2.19\%; Vujovic -23.65\%; de Cordova $-0.91 \%$ and Dansethakul 4.45\%. The correlation coefficient on Friedewald 0.9509; Anandaraja 0.9013; Puavilai 0.9576, Chen 0.9585; Vujovic 0.8745; de Cordova 0.9300 and Dansethakul 0.9505. The proposed $c L D L-C$ formula Chen et al promises in determining the LDL-C estimate and the Vujovic formula gives a poor result in this study. Validation methods should be applied to each of the cLDL formulas if they are to be applied to clinical laboratories.
\end{abstract}

Keywords: Cholesterol, LDL, Estimates

Abstrak: Pemeriksaan kolesterol-LDL (LDL-C) dapat dilakukan dengan melakukan estimasi LDL-C (cLDL-C) dalam darah. Selain formula Friedewald yang pertama kali diusulkan, beberapa formula baru yang menjanjikan pemeriksaan lebih baik dalam menentukan kadar LDL-C, diajukan oleh Anandaraja, Puavilai, Chen, Vujovic, de Cordova dan Dansethakul. Subjek penelitian adalah pasien yang melakukan pemeriksaan profil lipid rutin di Instansi Patologi Klinik Gedung Pusat Diagnostik Terpadu RSUD Dr. Soetomo Surabaya yang melakukan puasa 10 sampai 12 jam dengan TG kurang dari $400 \mathrm{mg} / \mathrm{dL}$. Sampel terdiri dari 41 laki-laki dan 48 perempuan dengan usia rata-rata 52 tahun. Uji Statistik pada masing-masing cLDL-C memberikan nilai bias Friedewald -1,32\%; Anandaraja -3,92\%; Puavilai 4,26\%, Chen -2,19\%; Vujovic -23,65\%; de Cordova $-0,91 \%$ dan Dansethakul 4,45\%. Koefisien korelasi pada Friedewald 0,9509; Anandaraja 0,9013; Puavilai 0,9576, Chen 0,9585; Vujovic 0,8745; de Cordova 0,9300 dan Dansethakul 0,9505. Formula cLDL-C yang diusulkan Chen dkk menjanjikan dalam menetapkan estimasi LDL-C dan formula Vujovic memberikan hasil yang buruk pada penelitian ini. Validasi metode perlu diterapkan pada masing-masing formula cLDL jika ingin diterapkan pada laboratorium klinik.

Kata kunci: Kolesterol, LDL, Estimasi

\section{PENDAHULUAN}

LDL (Low Density Lipoprotein) merupakan partikel lipoprotein yang aterogenik karena menjadi salah satu pemicu terbentuknya plak aterosklerosis (1). Perhimpunan Dokter Spesialis Kardiovaskular Indonesia dalam Buku Pedoman Tatalaksana Dislipidemia mejadikan LDL sebagai target terapi untuk mengurangi kasus Penyakit
Kardiovaskuler (PKV) dengan mengukur kadar kolesterol-LDL (LDL-Cholesterol, LDL-C) dalam darah (2).

Low density lipoprotein (LDL) dikenal juga sebagai kolesterol jahat yang banyak mengandung kolesterol dengan satu molekul apo B-100 (3). Komposisi partikel LDL terdiri dari $10 \%$ 
trigliserida, 50\% ester kolesterol, 29\% fosfolipid dan $11 \%$ kolesterol bebas (4). Struktur partikel LDL dapat dilihat pada Gambar 1.

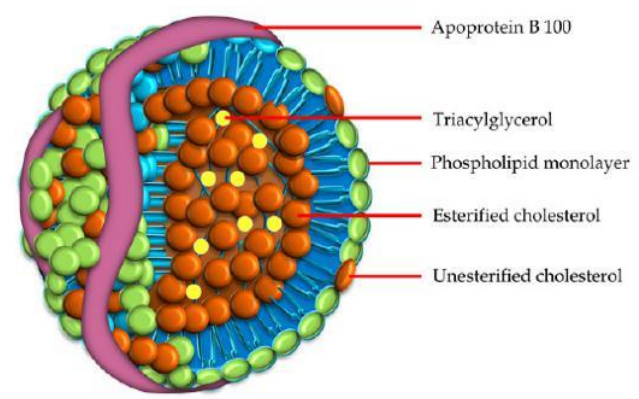

Gambar 1. Struktur partikel LDL (5)

Pembentukan LDL diawali dari partikel VLDL mengalami transfer apo C-II dan apo C-III kepada HDL (Nugraha et al. 2017). Sebaliknya, terjadi penambahan apo E dari HDL kepada VLDL. Pengurangan trigliserida dan perubahan komposisi apolipoprotein pada VLDL akan mengubah konformasi partikel lipoprotein menjadi lebih padat dan lebih kecil yang disebut IDL (Nugraha et al. 2017). Sekitar 50\% partikel IDL diambil oleh hati, sisa partikel IDL yang tidak diambil akan mengalami katabolisme lanjut. Lipase hati akan menghidrolisis sebagian besar trigliserida di dalam IDL yang akan mengubah konformasi apo E, diikuti oleh pemisahan apo E pada partikel sehingga terbentuk partikel LDL $(3,6,7)$.
LDL-C diukur menggunakan dua teknik, yaitu secara langsung yang juga dikenal dengan direk LDL-C (dLDL-C) dan tidak langsung yang juga dikenal dengan indirek LDL-C atau

calculated LDL-C (cLDL-C) dengan menggunakan formula $(8,9)$.

Pemeriksaan dLDL-C adalah teknik pengukuran kadar kolesterol dalam partikel LDL umumnya secara enzimatik dengan cara memisahkan partikel LDL dari lipoprotein yang lain. Tahapan selanjutnya, partikel lipoprotein dilakukan pengukuran kadar kolesterol (Nugraha et al. 2017). Teknik pemeriksaan ini dapat dilakukan dengan metode presipitasi atau asai homogen, perbedaan kedua teknik tersebut terletak dari cara pemisahan. Kolesterol LDL dikukur dengan metode pemeriksaan Kolesterol Total $(9,10)$.

Pemeriksaan cLDL-C adalah pengukuran LDL-C tanpa mengukur langsung partikel LDL. Pemeriksaan cLDL-C yang banyak digunakan di Indonesia adalah cLDL-C formula Friedewald (8). Beberapa tahun terakhir banyak di usulkan formula baru yang menjanjikan pemeriksaan lebih baik dalam menentukan kadar LDL-C, diantaranya adalah formula Anandaraja, Puavilai, Chen, Vujovic, de Cordova dan Dansethakul (11). Formula masing yang dikembangkan dapat dilihat pada Tabel 1.

Tabel 1. Berbagai macam formula cLDL-C

\begin{tabular}{|l|l|}
\multicolumn{1}{c|}{ Peneliti } & \multicolumn{1}{c|}{$\begin{array}{c}\text { Persamaan Kolesterol-LDL } \\
\text { Indirek }\end{array}$} \\
\hline Friedewald dkk (1972) & LDL $=$ TC - HDL-C - TG $/ 5$ \\
\hline Anandaraja dkk (2005) & LDL $=0,9 \mathrm{TC}-0,9 \mathrm{TG} / 5-28$ \\
\hline Puavilai dkk (2009) & LDL $=\mathrm{TC}-\mathrm{HDL}-\mathrm{C}-\mathrm{TG} / 6$ \\
\hline Chen dkk (2010) & $\mathrm{LDL}=90 \%$ kolesterol non-HDL - \\
& $10 \% \mathrm{TG}$ \\
\hline Vujovic dkk (2010) & $\mathrm{LDL}=\mathrm{TC}-\mathrm{HDL}-\mathrm{C}-\mathrm{TG} / 3$ \\
\hline de Cordova dan de Cordova (2013) & $\mathrm{LDL}=3 / 4(\mathrm{TC}-\mathrm{HDL}-\mathrm{C})$ \\
\hline Dansethakul (2015) & $\mathrm{LDL}=0,9955 \mathrm{TC}-0,9853 \mathrm{HDL}-\mathrm{C}$ \\
& $-0,1998 \mathrm{TG}+7,1449$ \\
\hline
\end{tabular}




\section{METODE PENELITIAN}

Subjek penelitian adalah pasien yang melakukan pemeriksaan profil lipid rutin di Instansi Patologi Klinik Gedung Pusat Diagnostik Terpadu RSUD Dr. Soetomo Surabaya. Sampel berupa serum dari pasien yang melakukan puasa 10 sampai 12 jam dengan TG kurang dari 400 $\mathrm{mg} / \mathrm{dL}$.

Semua serum dari pasien yang melakukan pemeriksaan profil lipid dilakukan pengukuran kadar TC, TG, HDL-C dan dLDL-C menggunakan Siemens Dimension ${ }^{\circledR}$ RxL Max ${ }^{\circledR}$ clinical chemistry system dan Flex ${ }^{\circledR}$ reagent cartridge dengan metode enzimatik di RSUD Dr. Soetomo Surabaya.

Pemeriksaan cLDL-C menurut Friedewald, Anandaraja, Puavilai, Chen, Vujovic, de Cordova dan Dansethakul dilakukan dengan cara perhitungan sesuai formula yang diusulkan masing-masing. Pengukuran dLDL-C dilakukan sebagai metode referen pemeriksaan, sehingga terdapat pembanding metode yang lebih baik terhadap metode cLDL-C yang sedang diteliti.

Analisis statistik dilakukan untuk uji akurasi, korelasi dan linieritas formula cLDL-C terhadap metode referen menggunakanExcel Office 2013.

\section{HASIL PENELITIAN}

\section{Karakteristik Sampel}

Sebanyak 89 sampel diambil untuk penelitian, sampel terdiri dari 41 laki-laki dan 48 perempuan dengan usia rata-rata 52 tahun. Karakteristik hasil pengukuran lipid pada penelitian ini dapat dilihat pada Tabel 2.
Tabel 2. Karakteristik hasil pengukuran lipid

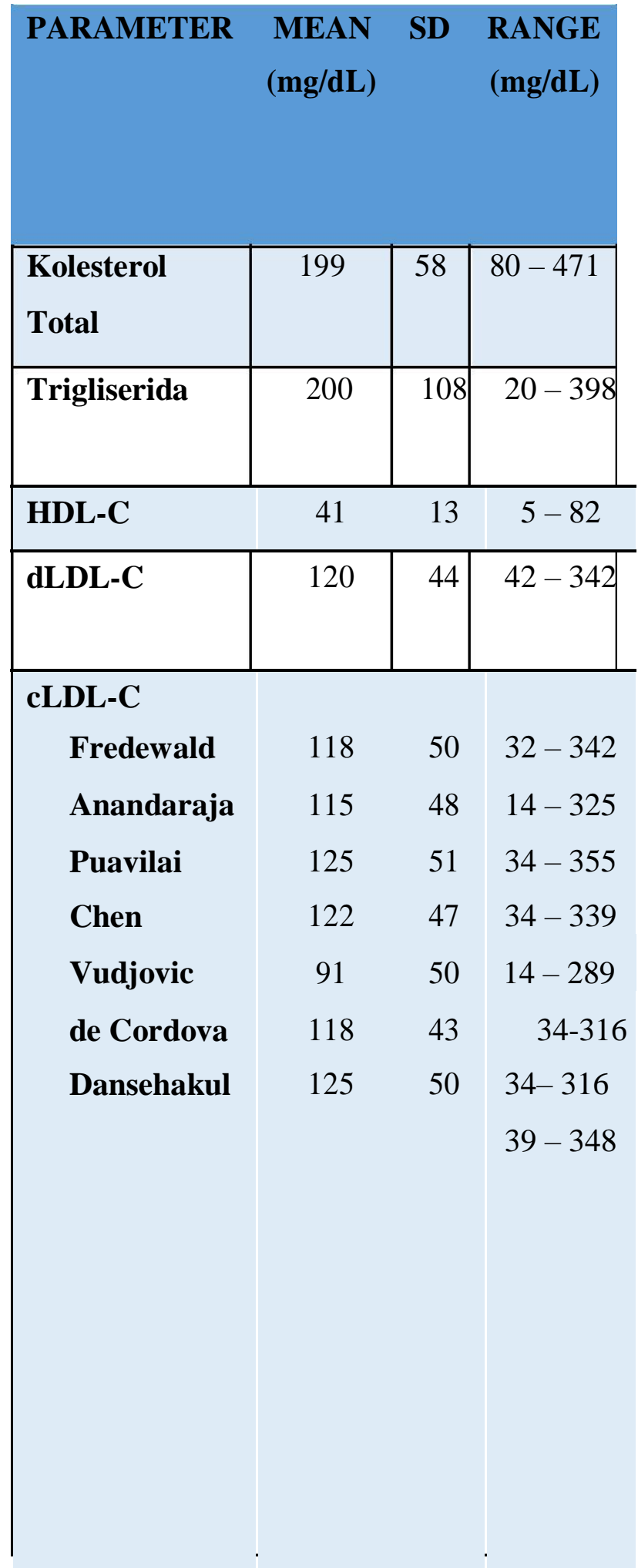

\section{Akurasi cLDL-C}

Akurasi ditetapkan sebagai nilai bias dari masingmasing formula cLDL-C terhadap metode referen. 
Nilai bias positif menunjukkan formula memberikan hasil lebih tinggi dibandingkan metode referen, nilai bias negatif menunjukkan formula memberikan hasil lebih rendah dibandingkan metode referen. Nilai bias pada masing-masing formula dapat dilihat pada Tabel 3.

Tabel 3 Nilai bias masing-masing formula

cLDL-C

\begin{tabular}{|l|l|}
\hline PARAMETER & $\begin{array}{c}\text { BIAS } \\
(\boldsymbol{\%})\end{array}$ \\
\hline Friedewald & $-1,32$ \\
\hline Anandaraja & $-3,92$ \\
\hline Puavilai & 4,26 \\
\hline Chen & $-2,19$ \\
\hline Vujovic & $-23,65$ \\
\hline de Cordova & $-0,91$ \\
\hline Dansethakul & 4,45 \\
\hline
\end{tabular}

Estimasi cLDL-C menggunakan formula de Cordova merupakan metode perhitungan yang memiliki akurasi lebih baik dibandingkan metode perhitungan lainnya pada trigliserida kurang dari $400 \mathrm{mg} / \mathrm{dL}$. Formula Friedewald memiliki akurasi terbaik ke dua yang selanjutnya berturutturut diikuti oleh formula Chen, Anandaraja, Puavilai, Dansethakul, dan akurasi yang terburuk pada formula Vujovic.

\section{Uji Korelasi dan Linieritas}

Uji korelasi dan linieritas dilakukan untuk mengetahui seberapa baik cLDL-C pada masingmasing formula dalam menentukan kadar kolesterol LDL yang sebenarnya dalam darah dengan menentukan seberapa dekat hasil pemeriksaan formula cLDL-C dengan pengukuran langsung LDL-C menggunakan metode homogeneous enzymatic assay. Tabel 4 memperlihatkan hasil uji korelasi dan analisis regresi linier pada masing-masing formula cLDLC.

\section{Tabel 4 Koefisien korelasi, koefisien determinasi dan persamaan regresi formula cLDL-C}

\begin{tabular}{|c|c|c|c|}
\hline $\begin{array}{l}\text { Formula } \\
\text { cLDL-C }\end{array}$ & $\begin{array}{l}\text { Koefisi } \\
\text { en } \\
\text { Korela } \\
\text { si }\end{array}$ & $\begin{array}{c}\text { Koefesie } \\
\text { n } \\
\text { Determi } \\
\text { nasi }\end{array}$ & $\begin{array}{c}\text { Persama } \\
\text { an } \\
\text { Regresi }\end{array}$ \\
\hline $\begin{array}{l}\text { Fredewal } \\
\text { d }\end{array}$ & 0,9509 & $90 \%$ & $\begin{array}{l}y \\
1,0867 x \\
-11,935\end{array}$ \\
\hline $\begin{array}{l}\text { Anandar } \\
\text { aja }\end{array}$ & 0,9013 & $81 \%$ & $\begin{array}{l}\mathrm{y} \\
0,9791 \mathrm{x} \\
-2,1879\end{array}$ \\
\hline Puavilai & 0,9576 & $91 \%$ & $\begin{array}{l}y \\
1,1083 x \\
-7,851\end{array}$ \\
\hline Chen & 0,9585 & $91 \%$ & $\begin{array}{l}y \\
1,0298 x \\
-0,9399\end{array}$ \\
\hline Vudjovic & 0,8745 & $76 \%$ & $\begin{array}{l}y \\
1,0004 x \\
-28,271\end{array}$ \\
\hline $\begin{array}{l}\text { de } \\
\text { Cordova }\end{array}$ & 0,9300 & $86 \%$ & $\begin{array}{l}y \\
0,912 x \\
9,4266\end{array}$ \\
\hline $\begin{array}{l}\text { Danseha } \\
\text { kul }\end{array}$ & 0,9505 & $90 \%$ & $\begin{array}{l}\mathrm{y} \\
1,0814 \mathrm{x} \\
-4,4078\end{array}$ \\
\hline
\end{tabular}




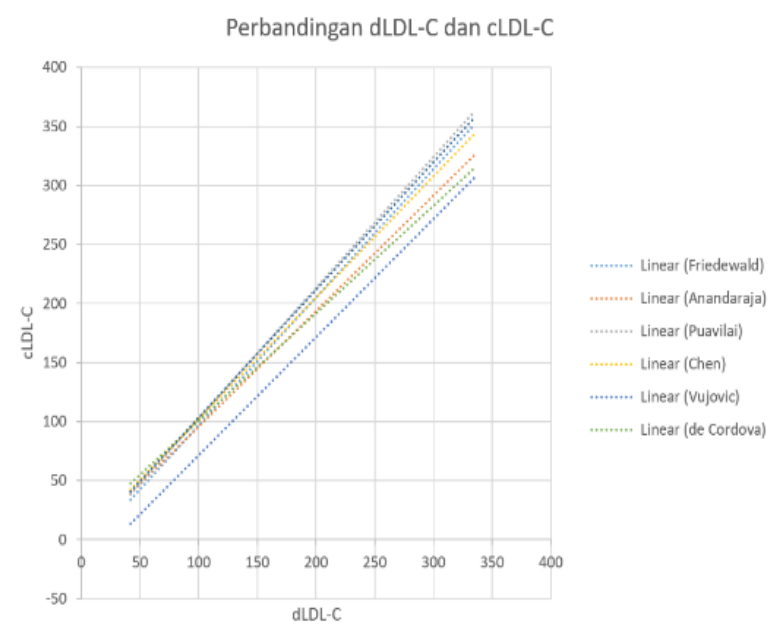

Gambar 2 Garis regresi linier pada berbagai macam formula cLDL-C

Gambar 2 memperlihatkan garis regresi linear pemeriksaan cLDL-C pada masing-masing formula, garis regresi pada masing-masing formula cLDL-C saling berdekatan kecuali formula Vujovic dengan kemiringan garis (slope) berbeda-beda pada formula.

Uji korelasi dan analisis regresi linier menunjukkan bahwa cLDL-C formula Chen memiliki kedekatan yang lebih baik dengan metode dLDL-C jika dibandingkan dengan formula lain walau slope dan intersep pada metode lain memiliki angka yang lebih kecil. Metode selanjutnya secara berturut-turut diikuti oleh formula Puavilai, Friedewald, Dansehakul, de Cordova, Anandaraja dan Vudjovic.

\section{KESIMPULAN}

Berbagai macam formula cLDL-C diusulkan paling baik dalam menetapkan kadar kolesterolLDL dalam darah, setelah dilakukan uji akurasi dan linieritas terhadap 89 sampel dengan trigliserida kurang dari $400 \mathrm{mg} / \mathrm{dL}$ didapat hasil yang bervariasi. Formula cLDL-C yang diusulkan Chen dkk menjanjikan dalam menetapkan estimasi kolesterol-LDL dalam darah dan menjadi alternatif pengganti formula Friedewald walau akurasi pemeriksaan Chen (Bias:-2,19\%) masih lebih baik pada formula de Cordova (Bias:-0,91\%) dan Friedewald (Bias:-1,32\%).

Formula Chen memperlihatkan performa yang terbaik pada penelitian ini, akan tetapi formula cLDL yang pertama kali diusulkan oleh Friedewald memperlihatkan hasil yang memuaskan dengan nilai bias yang kecil (Bias:$1,32 \%)$ dan korelasi yang cukup kuat (r:0,9509).

Formula cLDL-C yang diusulkan Vujovic memberikan hasil yang buruk pada penelitian ini, akurasi formula Vujovic memiliki bias yang cukup tinggi (Bias:-23,65\%) dan korelasi yang sangat rendah dibandingkan dengan formula lainnya (r:0,8745). Sehingga formula ini sangat tidak disarankan dalam menetapkan estimasi kolesterol-LDL dalam darah.

Validasi metode menurut ISO 17025 dan 15189 dapat diterapkan pada masing-masing formula cLDL jika ingin diterapkan pada laboratorium klinik, karena alat dan teknik pemeriksaan dapat mempengaruhi kualitas pemeriksaan dari masing-masing formula cLDLC tersebut.

\section{REFERENSI}

Hao W, Friedman A. 2014. The LDL-HDL Profile Determines the Risk of Atherosclerosis: A Mathematical Model. PLoS One [Internet]. 2014;9(3): e90497. Available from: http://dx.plos.org/10.1371/journal.pone.009 0497

Erwinanto, Santoso A, Putranto JNE, Tedjasukmana P, Suryawan R, Rifqi S, et al. 2013. Pedoman tatalaksana dislipidemia. J Kardiol Indones [Internet]. 2013;34(4):245-

70. Available from: http://jki.or.id

Feingold KR, Grunfeld C. 2015. Introduction to

Lipids and fatty acids [Internet].

MCText.com. 2015 [cited 2015 Oct 13]. p. 
1-11. Available from: http://www.ncbi.nlm.nih.gov/

Randolph GJ, Miller NE. 2014. Lymphatic transport of high-density lipoproteins and chylomicrons. J Clin Invest. 2014;124(3):929-35.

Legorreta V, Chávez-sánchez L, Chávez-rueda K, Blanco-favela F. 2014. The Innate Immune Response Mediated by TLRs in Atherosclerosis. In: Inflammation, Chronic Diseases and Cancer - Cell and Molecular Biology, Immunology and Clinical Bases. Mexico: InTech; 2014. p. 53-74.

Ramasamy I. 2013. Recent advances in physiological lipoprotein metabolism. Clin Chem Lab Med. 2013;52(1434-6621 (Electronic)):1-33.

Cohen DE, Fisher EA. 2013. Lipoprotein Metabolism, Dyslipidemia and Nonalcoholic Fatty Liver Disease. Semin Liver Dis. 2013;33(4):380-8.

Kemenkes RI. 2011. Pedoman Pemeriksaan Kimia Klinik. Jakarta; p. 147-57.

Burtis CA, Ashwood ER, Burns DE, Sawyer BG. 2012. Lipids, Lipoproteins, Apolipoproteins, and Other Cardiovascular Risk Factors. In: Fundamentals of Clinical Chemistry. 6th ed. Philadelphia: Saunders Elsevier; p. 402-27.

Kwiterovich PO. 2004. Laboratory procedure manual: total cholesterol, HDL-cholesterol, triglycerides, and LDL-cholesterol. Atlanta: Centers for Disease Control and Prevention. Dansethakul P, Thapanathamchai L, Saichanma S, Worachartcheewan A, Pidetcha P, Service E, et al. 2015. Determining a new formula for calculating low-density lipoprotein cholesterol: data mining approach. Exp Clin Sci Int online J. 2015;(14):478-83. 
